\title{
Extraction, purification and characterization of protease from Aspergillus Niger isolated from yam peels
}

\author{
Oludumila Omolara Racheal ${ }^{1, ~}$, Abu Temitope Folagbade Ahmed ${ }^{1}$, Enujiugha Victor Ndigwe ${ }^{1}$, \\ Sanni David Morakinyo ${ }^{2}$ \\ ${ }^{1}$ Department of Food Science and Technology \\ ${ }^{2}$ Department of Biochemistry; Federal University of Technology, P.M.B 704, Akure, Ondo State, Nigeria
}

\section{Email address:}

heniolarh@yahoo.com (Oludumila O. R.)

\section{To cite this article:}

Oludumila Omolara Racheal, Abu Temitope Folagbade Ahmed, Enujiugha Victor Ndigwe, Sanni David Morakinyo. Extraction, Purification and Characterization of Protease from Aspergillus Niger Isolated from Yam Peels. International Journal of Nutrition and Food Sciences. Vol. 4, No. 2, 2015, pp. 125-131. doi: 10.11648/j.ijnfs.20150402.11

\begin{abstract}
Protease was obtained from Aspergillus niger isolated from yam peels; a food waste, purified and characterized. Purification was achieved using ion exchange DEAE column and gel filtration (Sephadex G-200) chromatography. Effects of temperature; $\mathrm{pH}$ and production time on protease production were investigated. Also, physicochemical characteristics of the purified enzyme were investigated. The optimum production of protease was at temperature, $\mathrm{pH}$ and time of $37^{\circ} \mathrm{C}, 7.0$ and 42 hrs respectively. The results showed that purified protease had more specific enzymatic activity than crude samples from Aspergillus Niger. whereas the specific activity of crude enzyme was $0.51(\mathrm{U} / \mathrm{mg})$, while the purified enzyme had an improved specific activity of $8.51(\mathrm{U} / \mathrm{mg})$. Optimum temperature and $\mathrm{pH}$ values of the purified protease were found to be $50^{\circ} \mathrm{C}$ and 10.0 , respectively. $\mathrm{pH}$ stability of the enzyme ranged from 3.0-12.0. At 3.0 and 10.0 it retained $70 \%$ and $60 \%$ of its activity after 5 hrs of incubation. Temperature stability ranged between $30^{\circ} \mathrm{C}$ and $90^{\circ} \mathrm{C}$ but most stable at $50^{\circ} \mathrm{C}$ retaining $94 \%$ of its activity after $1 \mathrm{~h}$ of incubation. The enzyme exhibited maximum activity on casein, among other protein substrates. EDTA, $\mathrm{Cu}^{2+}, \mathrm{Fe}^{2+}$, $\mathrm{Mg}^{2+}$, and $\mathrm{Ca}^{2+}$ inhibited its activity while $\mathrm{Na}^{+}$enhanced it. The enzyme was purified 16.60-fold, had a yield of 10.96 and the apparent molecular weight was $46.90 \mathrm{kDa}$. The study revealed that protease from A. niger can be exploited for protein conversion biotechnologies.
\end{abstract}

Keywords: Protease, Aspergillus Niger, Yam Peels, Fermentation, Purification, Characterisation

\section{Introduction}

Waste is defined by (Oresanya, 1998) as any unwanted material intentionally thrown away for disposal. However, certain wastes may eventually become resources valuable to others once they are removed from the waste stream (Wiebe, 2003). Waste products arise from our ways of life and they are generated at every stage of process of production and development. Solid waste is used to describe non-liquid waste material arising from domestic, trade, commercial and public services. One of the most critical problems of developing countries is improper management of vast amount of wastes generated by various anthropogenic activities. More challenging is the unsafe disposal of these wastes into the ambient environment. Water bodies especially freshwater reservoirs are the most affected. This has often rendered these natural resources unsuitable for both primary and/or secondary usage (Fakayode, 2005). Wastes entering water bodies are both in solid and liquid forms. They are mostly derived from industrial, agricultural and domestic activities. The resultant effects of this on public health and the environment are usually great in magnitude (Osibanjo et al., 2011).

Edible foods are also wasted when cultural or individual preferences say that food is undesirable Both edible and inedible foods may be considered garbage and therefore wasted. Edible foods are considered inedible when their quality deteriorates until they become unhealthy or noxious. Deterioration of food occurs from microbial contamination or from rotting due to overproduction, storage problems, or improper preparation (Osibanjo et al., 2011).

Protease finds applications in various industries like 
detergent, leather, pharmaceutical, food and waste water treatment. Biotechnological importance of these enzymes has been realized by the leather industries in bating hides (Bhosale, 1995). Detergent industries tapped its potential in stain removal. In food industries they are used in crude preparations. In pharmaceutical industries they are useful as ingredients in preparing medicines (Rao et al., 1998).

This research justify the need to explore native fungal isolate, capable of producing proteases and at the same time relatively stable under prevailing operating conditions. The use of cheap agricultural residue (organic substrate) has enormous potential in reducing enzyme production cost. With this in mind, the objectives of the research were to: isolate and purify protease from fungi grown on yam peels, screen the isolates for protease, investigate and characterize the properties of the extracellular enzymes (protease) and investigate if the proteases obtained are relatively stable at operating condition.

\section{Materials and Methods}

Sources of Material: The material (yam peels) used in this study were sourced from a local fried yam seller in Akure metropolis, Ondo state, Nigeria. The yam peels were collected in clean cellophane bag, allowed to undergo natural bio- deterioration and transferred to the laboratory. All the reagent and chemicals used in the analysis were of analytical grade.

\subsection{Isolation, Inocula and Fermentation Medium for Protease Production}

Potato dextrose agar (PDA) with nutrients compositions of Potato Extract (Solid) 4g, Dextrose 20g, Agar 15g and pH 5.6 used for isolation was prepared according to the manufactures' specifications. Serial dilution was carried out while Potato dextrose agar (PDA) supplemented with $0.2 \mathrm{~g} / \mathrm{L}$ choramphenicol was used in the mycological analysis of Aspergillus niger. One milliliter of dilution 1:10 ${ }^{3}$ was transferred with a pipette into sterile plates. Molten agar cooled at $45^{\circ} \mathrm{C}$ was poured over the samples in each plate and then incubated at room temperature for $72 \mathrm{~h}$. The spores on the potato dextrose agar plates were counted using a digital illuminated colony counter model no.KA00-74A (B. Bran Scientific \&Instrument Co. England. Each distinct spore of fungi was transferred to freshly prepared potato dextrose agar plates for purification and incubated at room temperature for 72-168 h. The colonies forming clear zones around them were picked up and streaked on potato dextrose agar plates to get pure culture, and finally transferred to potato dextrose agar slants and maintained at $4{ }^{\circ} \mathrm{C}$.

Determination of optimum growth conditions: The protease production medium was modified according to the method of (Keay et al.,1972) to contain sucrose 250mg, casein $500 \mathrm{mg}$, locust beans $50 \mathrm{mg}$, di-potassium hydrogen phosphate $1 \mathrm{gm}$, magnesium sulphate $200 \mathrm{mg}$ per liter at $\mathrm{pH} 7$ at $28^{\circ} \mathrm{C}$ in an incubator $(200 \mathrm{rpm})$. The flask containing 100 $\mathrm{ml}$ of sterile fermentation medium was inoculated at $28^{\circ} \mathrm{C}$ for
$72 \mathrm{~h}$ in a rotary shaker regulated at $180 \mathrm{rpm}$. The culture medium was centrifuged at $3200 \mathrm{~g}$ for $1 \mathrm{~h}$ in a refrigerated centrifuge at $4^{\circ} \mathrm{C}$ to remove the fungal mycelia and medium debris. The supernatant was used as crude enzyme solution and was precipitated gradually up to $80 \%$ ammonium sulphate saturation. The precipitate after centrifugation at $3200 \mathrm{~g}$ for $30 \mathrm{~min}$ dissolved in minimal volume of $0.1 \%$ Tris$\mathrm{HCl}$ buffer ( $\mathrm{pH}$ 9) and was dialysed against $0.1 \mathrm{mM}$ potassium phosphate buffer for $48 \mathrm{~h}$ at $4^{\circ} \mathrm{C}$. The supernatant was collected and subjected to estimate the protease activity and protein content.

Assay of protease activity: Extracellular proteolytic activity was determined according to the modified method of Anson, (1938) as described in Thangam and Rajkumar (2002) using casein as the substrate. The reaction mixture contained $1 \mathrm{ml} 1 \%(\mathrm{w} / \mathrm{v})$ casein in $0.1 \mathrm{M}$ phosphate buffer $(\mathrm{pH} 7.0)$ and $1 \mathrm{ml}$ of culture supernatant. The mixture was incubated at $40^{\circ} \mathrm{C}$ for $30 \mathrm{~min}$. The enzyme reaction was terminated by addition of $6 \mathrm{ml} \mathrm{5 \%}(\mathrm{w} / \mathrm{v})$ trichloroacetic acid (TCA). The mixture was allowed to stand for $10 \mathrm{~min}$ and filtered through Whatman filter paper. To $1 \mathrm{ml}$ of filtrate, $3 \mathrm{ml}$ of $0.5 \mathrm{M}$ $\mathrm{Na}_{2} \mathrm{CO}_{3}$ solution and $1 \mathrm{ml}$ of 3 -fold-diluted Folin-Ciocalteu reagent (BDH Chemicals Ltd, Poole England) were added and mixed thoroughly. The colour developed after $30 \mathrm{~min}$ of incubation at $30^{\circ} \mathrm{C}$ and was measured in a Unico UV-2102 PC spectrophotometer at $660 \mathrm{~nm}$. One unit of protease activity was defined as the amount of enzyme required to liberate one microgram $(1 \mu \mathrm{g})$ of tyrosine from casein per minute at $40^{\circ} \mathrm{C}$ under the assay conditions described above.

Ion exchange chromatography (DEAE Sephadex A-50): Further purification of protease enzyme was carried out using DEAE (Di-ethyl amino ethyl) cellulose anion exchange chromatography. The dialysed sample was applied to a DEAE column. The column was washed with $50 \mathrm{mM}$, Tris buffer $\mathrm{pH} .8$, and eluted with serially increasing concentration of $\mathrm{NaCl}(0.1 \mathrm{M}, 0.2)$. The eluted fractions were monitored by UV absorption spectrophotometer at $280 \mathrm{~nm}$.

Gel Filtration Chromatography (using Sephadex G-200): Preparation of the gel column and the fractionation procedures was determined as mentioned by Ammar (1975). Sephadex G-200 (Pharmacia, Upsalla, Sweden) was used, $0.1 \mathrm{M}$ phosphate buffer of $\mathrm{pH} 7.0$ was added and the slurry was allowed to swell for 3 days at room temperature. Sodium azide $(0.02 \%)$ was added to prevent any microbial growth. The enzyme solution was collected and dissolved in phosphate buffer $0.1 \mathrm{M}$; pH 7.0 and fractionated through the Sephadex G-200 column $(2.6$ x $7.0 \mathrm{~cm})$ previously equilibrated with the same buffer. Seven (7) $\mathrm{ml}$ of the enzyme preparation sample was applied carefully to the top of the gel and allowed to pass into the gel by running the column. Buffer was added without disturbing the gel surface and to the reservoir. Elution was carried out with the respective buffer at a flow rate of $20 \mathrm{ml} / \mathrm{h}$. Fifty fractions ( $5 \mathrm{ml}$ each) were collected and absorbance read at $280 \mathrm{~nm}$ using spectrophotometer (Jenway, 6305). Protein and protease activity in the fractions were estimated. The eluted enzymatically active fractions were pooled and used as the 
purified enzyme.

SDS-Polyacrylamide gel electrophoresis: Sodium dodecyl sulphate-Polyacrylamide gel electrophoresis (SDS-PAGE) at $12 \%$ was carried out to determine the purity and molecular weight of the enzyme, as described by (Laemmli, 1970). The molecular weight of the enzyme was estimated using a low molecular weight calibration kit as markers consisting of bovine serum albumin $(66 \mathrm{kDa})$, egg white ovalbumin (45 $\mathrm{kDa})$, glyceraldehyde-3-P dehydrogenase (36 kDa), bovine carbonic anhydrase $(29 \mathrm{kDa})$, bovine trypsinogen $(24 \mathrm{kDa})$, soybean trypsin inhibitor $(20.1 \mathrm{kDa})$ and bovine -lactalbumin $(14.2 \mathrm{kDa})$. Protein bands were visualized after staining with Coomassie brilliant blue R-250.

Effect of $\mathrm{pH}$ on the activity of the enzyme: The optimum $\mathrm{pH}$ of the protease was investigated by the method of Yang et al., (1996) at $40^{\circ} \mathrm{C}$ and $\mathrm{pH}$ values ranging from 3-12 with $100 \mathrm{mM}$ of (citrate-phosphate buffer) $\mathrm{pH} \mathrm{3-7,} \mathrm{Tris-HCL}$ buffer $\mathrm{pH} 8-9$ and glycine-NaOH buffer (10-12). The effect of $\mathrm{pH}$ on protease activity was performed at $40^{\circ} \mathrm{C}$ in the different buffers at $100 \mathrm{mM}$ for $30 \mathrm{~min}$.

Effect of temperature on the activity of the enzyme: The optimum temperature was determined using the method of Rehman et al., (2011) by estimating the protease activity at $\mathrm{pH} 7$ and temperature ranging from $30-90^{\circ} \mathrm{C}$. It was carried out by incubating the enzyme at temperatures ranging from $30-90^{\circ} \mathrm{C}$ for $30 \mathrm{~min}$ and the residual activity was measured at $40^{\circ} \mathrm{C}, \mathrm{pH} 7$ and expressed as percentage residual activity.

Stability of the purified enzyme toward $\mathrm{pH}$ : The enzyme stability of purified enzyme was examined by measuring the residual activity of the enzyme being incubated for $5 \mathrm{~h}$ at $\mathrm{pH}$ 3-12 and temperature based on the method applied by Yang et al., (1996) and Rehman et al., (2011).The effect of $\mathrm{pH}$ on the activity of protease was measured by incubating $0.5 \mathrm{ml}$ of the diluted enzyme and $0.5 \mathrm{ml}$ of phosphate buffer ranging $\mathrm{pH}$ from 3 to 12 , containing $1 \%$ casein for $30 \mathrm{~min}$ at $40^{\circ} \mathrm{C}$.

Stability of the purified enzyme The effect of temperature on the enzyme activity was determined by performing the standard assay procedure for $30 \mathrm{~min}$ at $40^{\circ} \mathrm{C}, \mathrm{pH} 7.0$ between a temperature ranges of 30 to $90^{\circ} \mathrm{C}$, after which the residual enzyme activity was assayed for according to the method described earlier.

Determination of kinetic parameters: The Michaelis constant $\left(\mathrm{K}_{\mathrm{m}}\right)$ and the maximum reaction velocity $\left(\mathrm{V}_{\max }\right)$ of the protease for casein was determined at different substrate concentrations. They were evaluated by plotting the data on a Lineweaver-Burke double-reciprocal graph $(1 / \mathrm{Vo})$ versus $(1 /[\mathrm{S}])$ (Lineweaver and Burk, 1934).

\subsection{Effect of Metals ions and Enzyme Inhibitor on Protease Activity}

The effect of various metal concentrations on enzyme activity was investigated using $\mathrm{CaCl}_{2}, \mathrm{CuSO}_{4}, \mathrm{FeSO}_{4}$, $\mathrm{MgSO}_{4}, \mathrm{NaCl}$ and EDTA. The purified enzyme was preincubated with ions for $30 \mathrm{~min}$ at $40^{\circ} \mathrm{C}$ and then the remaining enzyme activity was estimated using casein as a substrate. The activity of the enzyme without metals was taken as the control.

\subsection{Substrate Specificity of the Purified Protease}

The ability of the purified protease to degrade various native proteins was evaluated with the following substrates $(1 \% \mathrm{w} / \mathrm{v})$. Casein, yeast extract, malt extract, beef extract, urea and peptone. Protease activity was determined as described earlier.

\section{Results}

Growth Culture of Aspergillus niger: The pattern of growth is illustrated in Figure 1.

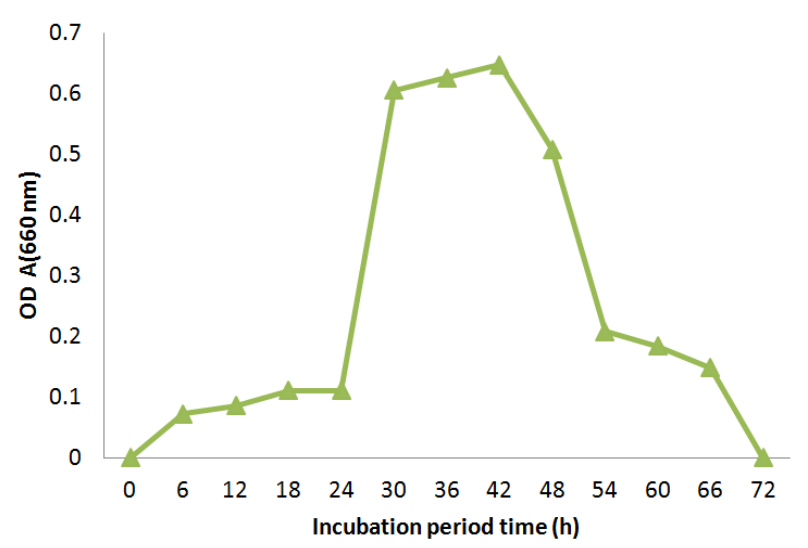

Figure 1. Fermentation profile of Aspergillus niger showing the growth and activity against time.

The exponential phase is observed immediately at $24 \mathrm{~h}$; the rate of growth was between $24 \mathrm{~h}$ to $48 \mathrm{~h}$ reaching peak growth at $42 \mathrm{~h}$ of incubation. The growth started declining at $48 \mathrm{~h}$ and the culture entered into the death phase. It was observed that there was a prolonged lag phase from $6 \mathrm{~h}$ to 24 $\mathrm{h}$ and sharp growth phase from $24 \mathrm{~h}$ to $42 \mathrm{~h}$ after which there was a gradual death phase from 48 to $72 \mathrm{~h}$.

Purification profile: Elution profile on ion exchange is shown in

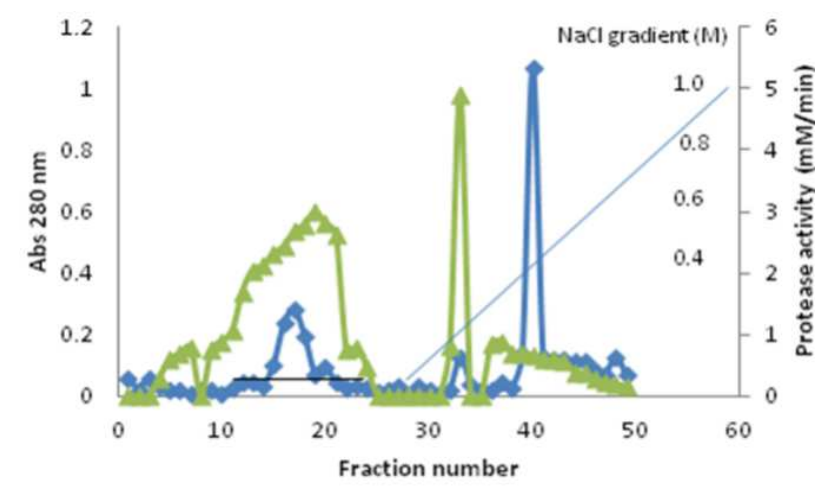

$\leadsto$ Abs $280 \mathrm{~nm} \quad$ Prote ase activity

Figure 2. Elution profile of protease from Aspergillus Niger by an ion exchange A-50 column.

Figure 2 while Gel filtration chromatogram is shown on 


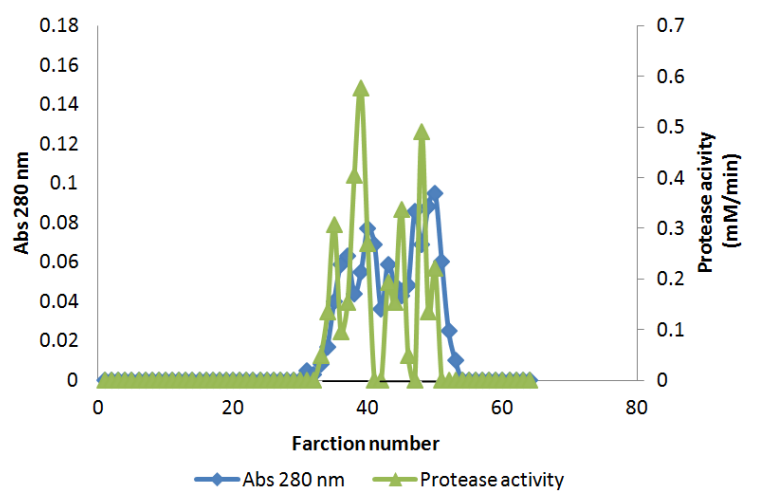

Figure 3. Purification elution profile of protease by gel filtration chromatography on Sephadex G-200.A further purification step.
Figure 3.

A summary of the results from the purification of protease is presented in Table 1 where it showed that specific activities for crude extract, ammonium sulphate precipitation, ion exchange chromatography, and gel filtration were 0.51 , $0.67,5.11$, and 8.51 (U/mg) respectively. Purification (fold) for crude extract, ammonium sulphate precipitation, ion exchange, and gel filtration were 1, 1.31, 9.96, and 16.60 respectively. Yield for gel filtration was 10.96, an indication that purification increased with each purification step while percentage enzyme yield reduced with each purification step. The Lineweaver-Burk plot of the protease activity indicates that the protease enzyme has apparent $\mathrm{K}_{\mathrm{m}}$ and $\mathrm{V}_{\max }$ values for casein hydrolysis of $40.13 \mathrm{mg} / \mathrm{ml}$ and $7.8 \mathrm{U}$ respectively.

Table 1. Purification of extracellular protease from Aspergillus niger

\begin{tabular}{llllllll}
\hline Steps & PC & EA & TEA & TP & SA & FOLD & YIELD (\%) \\
\hline Crude enzyme & 0.318 & 0.163 & 40.75 & 79.5 & 0.513 & 1 & 100 \\
$\left(\mathrm{NH}_{4}\right)_{2} \mathrm{SO}_{4}$ precipitation and dialysis & 0.297 & 0.200 & 25.0 & 37.13 & 0.673 & 1.31 & 61.35 \\
DEAE- cellulose & 0.110 & 0.564 & 4.5 & 0.88 & 5.11 & 9.96 & 11.04 \\
Sephadex G-200 & 0.070 & 0.596 & 4.47 & 0.525 & 8.51 & 16.60 & 10.96 \\
\hline
\end{tabular}

PC: Protein concentration $(\mathrm{mg} / \mathrm{ml})$

EA: enzyme activity $(\mathrm{mm} / \mathrm{min})$

TEA: total enzyme activity $(\mathrm{mm} / \mathrm{min})$

TP: Total protein

SA: Specific activity

SDS-PAGE Electrophoresis: The electrophotorectogram of purified protease (PP) is shown in

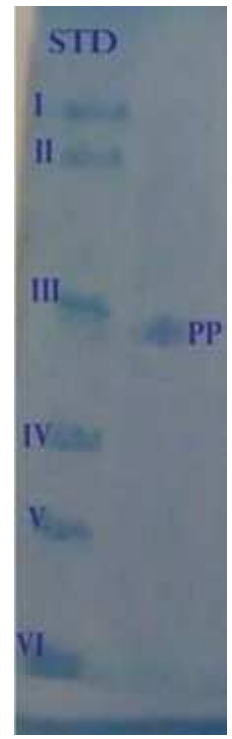

Figure 4. Electrophorectogram of purified protease (PP) by a combination of ion exchange chromatography and gel filtration chromatography on Sephadex.

Figure 4. Purified protein was analyzed on $10 \%$ Bis -Tris gel. Standard protein marker consisted of (I) Phosphorylase b, $103.14 \mathrm{kDa}$; (II) Bovine serum albumin, $81.35 \mathrm{kDa}$; (III) Ovalbumin, 47.05 kDa; (IV) Carbonic anhydrase, $34.17 \mathrm{kDa}$; (V) Soybean trypsin inhibitor, $27.26 \mathrm{kDa}$ and (VI) Lysozyme, $17.67 \mathrm{kDa}$. The protein band occurred as a single band and it was spotted between protein standard iii and iv. The estimated molecular weight for purified protease was 46.90 $\mathrm{KDa}$.

Effect of $\mathrm{pH}$ on the Activity and Stability of Protease: The influence of $\mathrm{pH}$ on activity of the protease is shown in

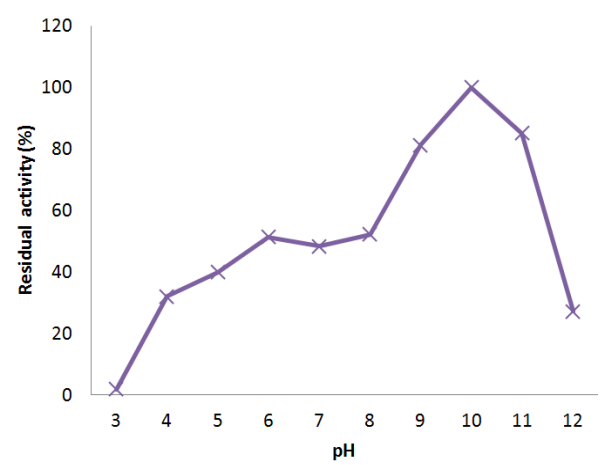

Figure 5. Effect of $p H$ on the residual activity of protease

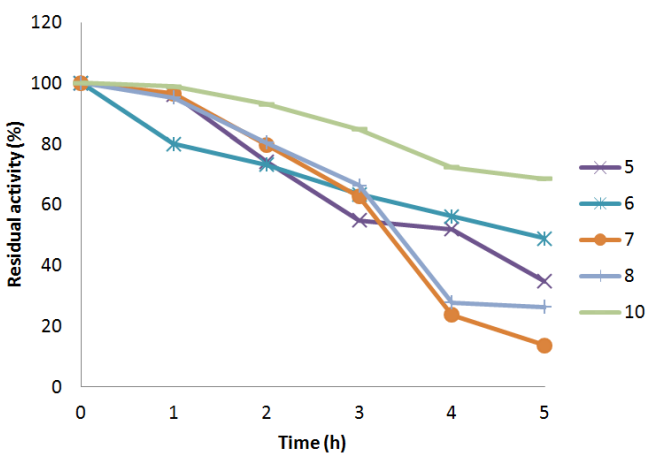

Figure 6. Effect of $p H$ on the stability of protease activity

It revealed optimum $\mathrm{pH}$ at $\mathrm{pH} 10$. At $\mathrm{pH} 11$ and 12 the 
enzyme was relatively stable and at lower $\mathrm{pH}$ it was observed that activity was low at $\mathrm{pH} 3-7$. At $\mathrm{pH} 8$ there was a sharp and sudden increase in the activity which makes the enzyme more stable at alkaline $\mathrm{pH}$.

The $\mathrm{pH}$ stability is shown on Figure 6 depicting residual activity against time. At $\mathrm{pH} 10-12$ over a time of $5 \mathrm{~h}$ the enzyme was relatively stable and had residual activity of 70 $55 \%$. At pH lower than 10 the enzyme was not stable with residual activity ranging from $55-20 \%$. Also from the plot, the enzyme was relatively stable at $\mathrm{pH} 9$ to 12 than at $\mathrm{pH} 3$ to 8 for a time of $5 \mathrm{~h}$.

Effect of Temperature on the Activity and Stability of Protease.

The effect of temperature on the enzyme is shown on

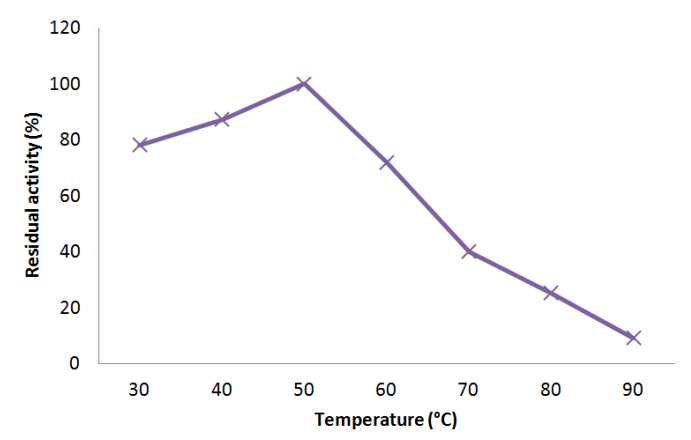

Figure 7. Effect of temperature on the activity of protease from Aspergillus Niger

Figure 7. At temperature ranging between $30-50^{\circ} \mathrm{C}$, the activity was high, while the optimum temperature was at $50^{\circ} \mathrm{C}$. There was a sharp and steady decrease in activity from $60-90^{\circ} \mathrm{C}$. It was observed that, the higher the temperature the lower the activity. The thermostability of protease at various temperatures is shown in

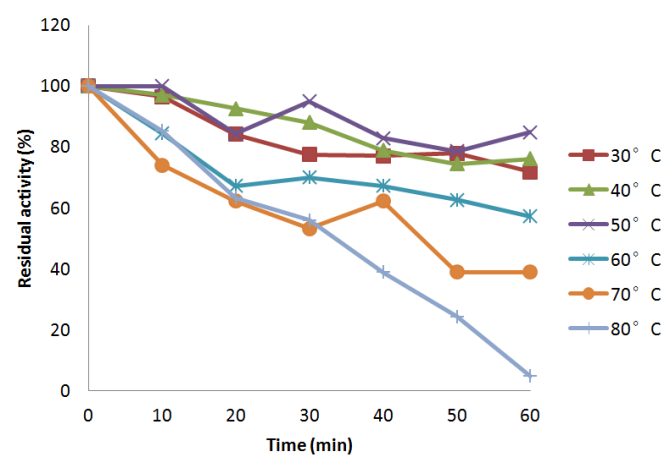

Figure 8. Temperature stability of the activity of protease from Aspergillus Niger

Figure 8 , where it was revealed that protease was more stable from $30-60^{\circ} \mathrm{C}$, after an hour of incubation. At higher temperature, there was a decline in residual activity. At incubation time of $20 \mathrm{~min}$ it was observed that residual activity was high at temperatures between $30-50^{\circ} \mathrm{C}$ and at temperatures between $60-90^{\circ} \mathrm{C}$ the residual activity was moderate.

Effect of metal salts and inhibitor: The effect of various metals ions in

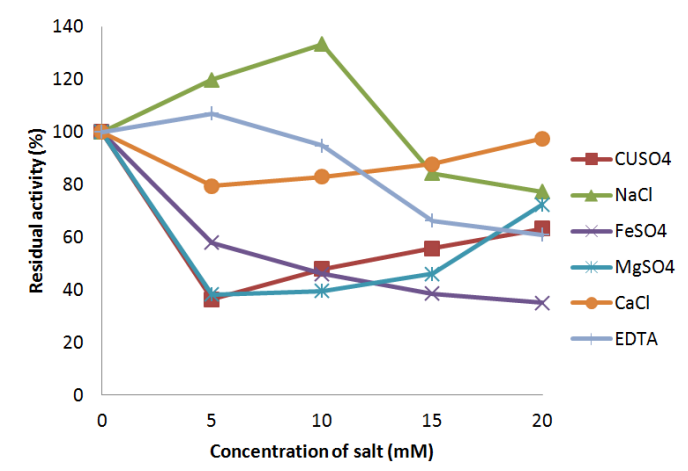

Figure 9. Effect of metallic ions on the activity of protease from Aspergillus Niger

Figure 9 shows that $\mathrm{FeSO}_{4}, \mathrm{MgSO}_{4}$ and $\mathrm{CuSO}_{4}$ inhibited protease activity while EDTA, $\mathrm{NaCl}_{2}$ and $\mathrm{CaCl}_{2}$ inducted the protease activity respectively.

Effect of different protein substrate on protease:

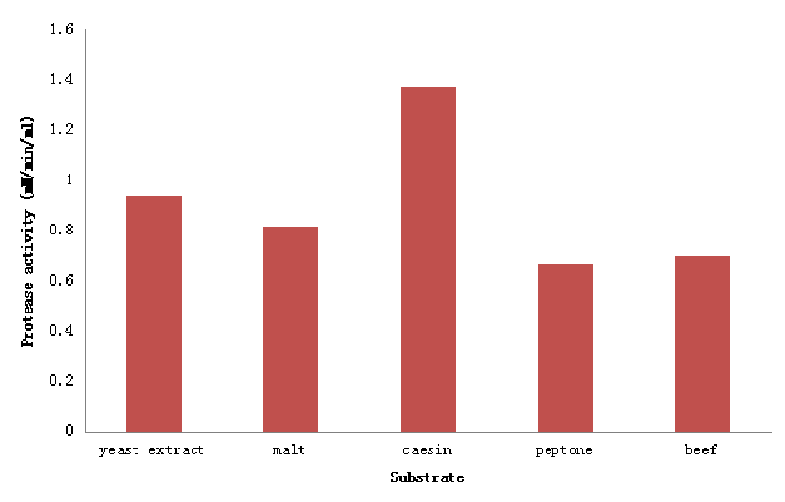

Figure 10. Effect of different protein substrates on protease activity.

Figure 10 shows the substrate specificity of protease. Different protein substrates at $1 \%$ concentration were used and it was found that maximum protease activity was observed in casein followed by yeast extract. The least activity was observed in peptone followed by beef extract and urea.

\section{Discussion}

Incubation time shows the result for optimal incubation period. This indicated that protease yield increased gradually and attained high titer of enzyme activity $(280 \mathrm{U} / \mathrm{g})$ at $42 \mathrm{~h}$ of incubation after which there was declination and the growth was eventually terminated at $72 \mathrm{~h}$, further incubation reduced the yield. (Chakraborty et al., 1995) isolated a new fungal isolate identified as Aspergillus Niger with the capacity to produce enormous amounts of a highly acidic extracellular protease on solid substrate. The fungus can be grown on inexpensive substrate and is capable of producing high yield of protease and relatively stable at the operating condition (Mulimani et al., 2002).

The optimum temperature of the purified protease was $50^{\circ} \mathrm{C}$. The result revealed that the protease retained a considerable amount of its activity at low temperatures. The 
protease retained up to $94 \%$ of its original activity at $50^{\circ} \mathrm{C}$. It reduced to about $28 \%$ of the original activity at $80^{\circ} \mathrm{C}$, respectively. This indicates that the protease was considerably stable at low temperatures. The optimum temperature of the protease is consistent with the protease of A. terreus $50^{\circ} \mathrm{C}$ (Bushra et al., 2010); and A. oryzae $50^{\circ} \mathrm{C}$ (Sumantha et al., 2005).

Thermostability study of this enzyme at $50^{\circ} \mathrm{C}$ shows potential for applications in food industries such as baking, brewing etc. The enzyme of Rhizopus oryzae acted optimally at $60^{\circ} \mathrm{C}$ and was stable in the temperature range of $30-45^{\circ} \mathrm{C}$. The acid protease of Mucor rouxii showed temperature optima of $50^{\circ} \mathrm{C}$ and was inactivated at $70^{\circ} \mathrm{C}$. (Tremacoldi et al., 2004) reported temperature optima of $40^{\circ} \mathrm{C}$ by acid protease of Aspergillus clavatus. The result was also different from the protease of $A$. Niger $\left(32^{\circ} \mathrm{C}\right)$ (Aalbaek etal., 2002). In addition, unlike other fungal proteases, $A$. Niger protease exhibited unique wide range thermostability even at low temperatures for $30 \mathrm{~min}$ incubation. The enzyme retained about $55 \%$ of its original activity at $90^{\circ} \mathrm{C}$. The purified protease was completely stable at $50^{\circ} \mathrm{C}$ and is consistent with some previous reports (Sumantha et al., 2005; Wang et al., 2005). The temperature and stability profile of the purified protease suggested that the enzyme was thermostable. However, this enzyme could find potential commercial application as a food processing agent since most food industries such as brewing, baking, etc. that utilize proteases require their processes to be carried out at temperatures around 50 and $60^{\circ} \mathrm{C}$.

The purified protease exhibited a very unique $\mathrm{pH}$ profile. The enzyme displayed broad range of activity at acidic, basic and neutral levels. The optimum activity was at $\mathrm{pH} 10.0$, but equally exhibited remarkable activity at $\mathrm{pH} 7.0$ and 11.0. The data is similar to literature reports particularly that fungi may secrete acidic, neutral and alkaline proteases (Siala et al., 2009; and Sumantha et al., 2005). The wide activity range ( $\mathrm{pH} 3.0$ to 12.0) of the protease from this research work contrasts markedly with the narrow $\mathrm{pH}$ range (3.0 to 4.0) observed for CtsD from $A$. Niger ATCC 26933 (Vickers et al., 2007). The purified protease from $A$. Niger was very stable at $\mathrm{pH}$ 11.0. However, the result of this study differs from $A$. clavatus protease. This indicates that the protease exhibited broad activity at acidic, basic and alkaline range.

In enzyme action, metallic cofactors are important because their presence or absence regulates enzyme activity. The presence of specific metallic ions along with peels from food can inhibit or enhance protease activity. Inhibitors and metal chelators can reduce the hydrolysis of substrate by proteolytic enzymes. Due to their specificity, inhibitors and chelators can also aid in characterization of novel proteases by examining hydrolysis rates of protease in their presence. The inhibition studies of the purified protease indicated that specific metallo-protease inhibitors, a chelator's agent, EDTA significantly stimulated the protease suggesting that the protease is not a metallo-protease. The high activity of the enzyme in the presence of EDTA is very useful for application as detergent additive. These observations indicate that the $A$. niger protease is a thiol (cysteine) protease. To this end, the protease could be of great potential in brewing industries and in meat tenderization where it is used to remove protein hazes.

The strong activation of the protease in the presence of $\mathrm{Mg}^{2+}$ suggests that the protease could be protected from thermal denaturation due to their probable presence in the catalytic domain of the enzyme. The involvement of $\mathrm{Mg}^{2+}$ and $\mathrm{Ca}^{2+}$ in the protection of protease thermal denaturation has been reported (Kumar and Tagagi, 1999). $\mathrm{Na}^{+}$was slightly inhibitory to the protease.

The important feature of proteases is their ability to discriminate among competing substrates and utility of these enzymes often depends on their substrate specificity (Shankar et al., 2011). The purified protease was able to degrade natural substrates like yeast extract, malt extract, peptone, urea, casein and beef extract to varying degrees. It was more active against casein compared to yeast extract, malt extract, peptone, urea and beef extract. The ability to degrade casein by this enzyme is consistent with the report of (Shankar et al., 2011). The substrate specificity profile of the purified protease indicates that the enzyme has a wide range of hydrolytic activity on various protein substrates which is a great potential in biotechnological applications. The result confirms that sources of substrate significantly affected both affinity and digestibility of the substrates by the protease.

The kinetic parameter (Vmax and $\mathrm{Km}$ ) values 7.8 and 40.13 respectively confirmed that the purified protease possessed high affinity and degradability. (Shankar et al.,2011) has reported protease with Km value of 5.1 mgml-1 with casein as substrate from Beauveria sp. Report from (Devi et al., 2008) gave a lower Km values of $0.8 \mathrm{mgml}-1$ using casein. When assayed with native protein as substrates, the protease showed high level of hydrolytic activity with all the substrates tested with highest specificity for casein $(130 \%)$, indicating broad substrate specificity of this enzyme (Wang et al., 2005).

With an approximate 17-fold purification and overall yield of $10.96 \%$, during passage through the ion-exchange column, the enzyme of interest eluted as an unbound fraction. Gel filtration chromatography depicted only one activity peak. In a Brilliant Blue G-Colloidal Concentrate stained SDS-PAGE gel, the protease migrated as a single band with an estimated molecular weight of $46.90 \mathrm{kDa}$. These observations indicate that the enzyme is homogeneous and probably monomeric. However, bands of unknown contaminant proteins were observed. Zymogram analysis revealed that only a single protein band possessed proteolytic activity which corresponded with the molecular weight of $46.90 \mathrm{kDa}$ on SDS-PAGE. This confirms that the other minor bands were contaminant proteins. The molecular weight of the protease is at variance with other literature reports on fungi. The molecular weight of $A$. Niger protease is higher than that reported for Beauveria sp $29 \mathrm{kDa}$ (Shankar et al., 2011); A. terreus $35 \mathrm{kDa}$ (Bushra et al., 2010). The value was comparable with 75 and $74 \mathrm{kDa}$ reported for Pleurotus ostreatus protease (Palmieri et al., 2004). 


\section{Conclusion}

This work describes the purification and characterization of Aspergillus niger strain from protease. The enzyme was purified from the culture supernatant by two steps with a 16.60 -fold increase in specific activity and $10.96 \%$ recovery. The result from the study has shown that protease can be produced from Aspergillus niger isolated from yam peels which is a food waste. From the physicochemical studies it was revealed that the enzyme could be of good use for industrial purposes, such as food, pharmaceutical, cosmetic, etc.

\section{References}

[1] Aalbaek, T., Reeslev, M., Jensen, B., and Eriksen, S. H. (2002). Acid protease and formation of multiple forms of glucoamylase in batch and continuous cultures Aspergillus niger. Enzyme Microbiol. Technol., 30: 410-415.

[2] Anson, M. L., (1938). The estimation of pepsin, trypsin, papain and cathepsin with hemoglobin, J. General physiol., 22: 79-89.

[3] Bhosale, S. H., Rao, M. V., Deshpande, V. V. and Srinivasan, M. C. (1995). Thermostability of high activity alkaline protease from Conidiobolus coroinatus [N(L)86.8.20]. Enzyme Microbio.Technol. 17, 136-139.

[4] Bushra, M., Ahsan, H., Abdul, M. and Hassan Z., (2010). Purification and characterization of alkaline protease from Aspergillus terreus. J. Chem. Soc. Pak., 32: 497-503

[5] Chakraborty, R., Srinivasam, M., Sarkar, S. K. and Raghavan, K.V., (1995).Journal of Microbiology and Biotechnology, 10 (1), 17-30.

[6] Devi, M. K., Banu, A. R., Gnanaprabhal, G. R., Pradeep, B. V. and Palaniswamy, M., (2008). Purification, characterization of alkaline protease enzyme from native isolate Aspergillus niger and its compatibility with commercial detergents. Indian J. Sci. Technol., 1:1-6.

[7] Fakayode, S. O., (2005). Impact assessment of industrial effluent on water quality of the receiving Alaro river in Ibadan Nigeria AJEAM-RAGEE 10: 1-13.

[8] Keay, L., Mosley, M. H., Anderson, R. G., O'Connor, R. J. and Wildi B.S., (1972). Production and isolation of microbial proteases, Biotechnol.Bioeng. Symp. 3, 63-92.

[9] Kumar, C. G. and Takagi, H., (1999). Microbial alkaline proteases from bio-industrial view point biotechnology.Adv.17:561-594Liang, T. W., Lin, J. J., Yen, Y. H., Wang, C. L. and Wang, S. L., (2006). Purification and characterization of a protease extracellularly produced by Monascus purpureus ccrc31499 in a shrimp and crab shell powder medium. Enzyme Microbial Technol., 38: 74-80.

[10] Lineweaver, H. and Burk, D., (1934). The determination of enzyme dissociation constants. J. Am. Chem. Soc., 56: $658-$ 666.

[11] Lowry, O. H., Rosebrough, N. J., Farr, A. L. and Randal, R. J., (1951). Journal of biological chemistry, 193: 265 -275.

[12] Mulimani,V. H., Patil, G. N. and Prashanth, S. J., (2002).
Bleach stable and Alkali-Tolerant Protease from Aspergillus flavus. Ind.J. Microbiol. 42, 55-58.

[13] Oresanya, O., (1998). Waste control measures and responsibility of a waste manager within the framework of recent management methods and development in municipal and industrial wastes. Paper presented at the workshop on effective waste management in nigeria organized by the Nigerian society of Engineers, Lagos. April.

[14] Osibanjo,O., Daso, A. P. and Gbadebo, A. M., (2011). The impact of industries on surface water quality of river Ona and river Alaro in Oluyole industrial estate, Ibadan, Nigeria Afr. J. Biotechnol. 10 (4): 696-702.

[15] Palmieri, G., Bianco, C., Cennamo, G., Giardina, P., Marino, G., Monti, M. and Sannia, G., (2001). Purification, characterization, and functional role of a novel extracellular protease from Pleurotus ostreatus. Appl. Environ. Microbiol., 67: 2754-2759.

[16] Rao, M. B., Tanksale, A. M., Ghatge, M. S. and Deshpande V., (1998). Molecular and biotechnological aspects of microbial proteases, Microbiol. Mol. Biol. Rev. 62, 597-635.

[17] Rehman, A., Shafaat, S. and Akram M. (2011). Isolation and characterization of a thermostable $\alpha$ - amylase from bacillus subtilis. African journal of Microbiology Research Volume 5 (20) pp 3334-3338

[18] Shankar, S., Rao, M. and Laxman, R. S., (2011). Purification and characterization of an alkaline protease by a new strain of Beauveria sp. Process Biochem., 46: 579-585.

[19] Siala, R., Sellami-Kamoun, A., Hajji, M., Abid, I., Gharsallah, N. and Nasri, M., (2009). Extracellular acid protease from Aspergillus niger I1: purification and characterization. Afr. J. Biotechnol., 8: 4582 - 4589.

[20] Sumantha, A., Sandhya, C., Szakacs, G., Soccol, C. R. and Pandey, A., (2005). Production and partial purification of a neutral metalloprotease by fungal mixed substrate fermentation. Food Technol. Biotechnol., 43(4): 313-319.

[21] Tremacoldi, N. K., Watanabe, E. C. and Carmona, E. C., (2004). Production of extracellular acid proteases by Aspergillus clavatus, World J. Microbiol. Biotechnol. 20, 639642.

[22] Thangam, B. E. and Rajkumar, S. G., (2002). Purification and characterization of alkaline protease from Alcaligenes faecalis. Biotechnol. Appl. Biochem., 35: 149-154.

[23] Vickers, I., Reeves, E. P., Kavanagh, K. and Doyle, S., (2007). Isolation, activity and immunological characterization of a secreted aspartic protease, CtsD, from Aspergillus fumigatus. Protein Expression and Purification, 53: 216-224.

[24] Wang, S. L., Chen, Y. S., Wang C. L., Yen, Y. H. and Chern, M. K., (2005). Purification and characterization of a serine protease extracellularly produced by Aspergillus fumigatus in a shrimp and crab shell powder medium. Enzyme Microbiol. Technol., 36: 660-665.

[25] Wiebe, M. G., (2003). Stable production of recombinant proteins in filamentous fungi - Problems and improvements, Mycologist,17: 140-144.

[26] Yang, Z., Michael, D., Robert, A., Fang, X. Y., and Alan, J.R (1996). Polyethylene glycol-induced stabilization of subtilism. Enzyme Microb. Technol, 18, 82-89. 